\title{
MANAJEMEN MULTI KULTUR DI SEKOLAH
}

\author{
Fahruljamil \\ Visi Nusantara \\ fahruljamil5@gmail.com
}

\section{Pendahuluan}

Pembaharuan administrasi bidang pendidikan di Indonesia terus mengalami upaya-upaya perbaikan, dalam rangka menghadapi tantangan yang semakin kompleks. Pembaharuan atau perkembangan yang dialami administrasi pendidikan dengan sendirinya akan merubah makna atau rumusan tentang administrasi pendidikan. Berkaitan dengan hal tersebut, perlu dicermati lebih lanjut berbagai konsep manajemen yang utuh, agar konsep-konsep tersebut dapat dipilih secara selektif, disesuaikan dengan nilai-nilai budaya organisasi dan pada akhirnya dapat dimanfaatkan bagi pencapaian tujuan organisasi. Salah satu konsep manajemen yang ada pada antara era industri akhir (Genarasi IV) ke era pengetahuan awal (Generasi V) adalah konsep manajemen multi budaya.

Manajemen merupakan bagian yang sangat penting dalam sistem organisasi, termasuk organisasi pendidikan, yang didalamnya terintegrasi konsep perencanaan, pengorganisasian, pelaksanaan dan pengawasan (evaluasi). Oleh karena itu, apabila salah satu sub sistem tadi kurang berperan dengan baik, maka akan terjadi mis management atau kekeliruan dalam mengelola manajemen. Jadi bukan sekedar "salah urus" yang cenderung hanya menekankan pentingnya pelaksanaan.

Manajemen dengan berbagai konsep dan jenisnya berkembang pesat terutama di organisasi bisnis, yang tentu saja dengan modifikasi-modifikasi tertentu dapat dimanfaatkan oleh organisasi pendidikan, sebagai organisasi berkategori non profit. Untuk itu, tulisan ini akan mencoba menguraikan konsep manajemen multi budaya yang dapat dipergunakan di sekolah. Makna manajemen multi budaya (pluralisme budaya) ialah upaya mengelola budaya yang berbeda-beda, memberdayakannya sehingga dapat meningkatkan kinerja suatu organisasi, baik secara internal maupun eksternal. Budaya dapat diartikan sebagai cipta, rasa, karsa/karya seseorang/kelompok, bangsa, organisasi, yang berarti ada keragaman nilai, baik secara individu, kelompok dalam organisasi bisnis maupun non profit.

Pemahaman manajemen multi budaya sangat penting, karena keragaman yang bersifat multi budaya dalam struktur dan komposisi angkatan kerja (personal), adanya perpaduan budaya 
organisasi yang berbeda (misalnya dalam kasus merger, kerja sama), kegiatan-kegiatan yang bersifat global, kegiatan-kegiatan dalam kawasan-kawasan baru yang terpadu, pluraslisme masyarakat dalam suatu negara, sehingga diperlukan suatu seni dan ilmu manajemen ke dalam konteks budaya. Keragaman budaya itu dapat saling mengenal, saling menghargai, sehingga tercapai kondisi simbiose metualistis alam keragaraman tersebut.

Esensi dari manejemen multi budaya terletak pada komunikasi, baik melalui kata-kata, benda material, maupun perilaku didasarkan pada imformasi yang sebaik mungkin tentang keragaman budaya tersebut (Hall \& Hall, 1987 dalam Elashmawi \& Haris, 1999:4-27).

Sejak berkomunikasi antar personal apakah kegiatan bisnis atau keperluan lainnya (seperti misalnya berjabat tangan, pembicaraan telepon, negosiasi, seminar, pelatihan, berunding, rapat dan lainnya), sebenarnya telah terjadi tentang budaya, yang hanya sukses kalau pihak-pihak yang berkomunikasi sadar, mengerti serta hormat terhadap nilai dan perbedaan orang lain, kelompok lain, suku atau bangsa lain. Lebih lanjut, menghargai keragaman budaya, berarti menghargai nilai-nilai budaya (sendiri atau pihak lain), lebih-lebih prioritas nilai budaya yang diutamakan, serta menjalin komunikasi lintas budaya.

\section{Penerapan Konsep Manajemen Multi Budaya di Sekolah}

Dengan memahami konsep tentang manajemen multi budaya sebagaimana telah diutarakan di atas, selanjutnya di bawah ini akan diuraikan tentang penerapan konsep manajemen multi budaya dalam konteks persekolahan.

Berbicara tentang manajemen multi budaya, tidak terlepas dari kajian tentang budaya organisasi, yang memuat nilai-nilai atau kepercayaan yang dimiliki oleh individu dan organisasi. Dalam konteks persekolahan, nilai-nilai yang dimiliki dan dikembangkan di sekolah, tentunya tidak dapat dilepaskan dari keberadaan sekolah itu sendiri sebagai organisasi pendidikan, yang memiliki peran dan fungsi untuk berusaha mengembangkan, melestarikan dan mewariskan nilainilai budaya kepada para siswanya. Dalam hal ini, Larry Lashway (1996) menyebutkan bahwa “schools are moral institutions, designed to promote social norms,..." .

Nilai-nilai yang mungkin dikembangkan di sekolah tentunya sangat beragam. Jika merujuk pada pemikiran Spranger (Sumadi Suryabrata, 1990), maka setidaknya terdapat enam jenis nilai yang seyogyanya dikembangkan di sekolah, yaitu ilmu pengetahuan, ekonomi, kesenian, keagamaan, kemasyarakatan, dan politik atau kenegaraan. 
Sementara Fred Luthan dan Edgar Schein, melihat karakteristik budaya organisasi di sekolah, sebagai berikut yaitu obeserved behavioral regularities, norms, dominant value, philosophy, rules dan organization climate.

Obeserved behavioral regularities; budaya organisasi di sekolah ditandai dengan adanya keberaturan cara bertindak dari seluruh anggota sekolah yang dapat diamati. Keberaturan berperilaku ini dapat berbentuk acara-acara ritual tertentu, bahasa umum yang digunakan atau simbol-simbol tertentu, yang mencerminkan nilai-nilai yang dianut oleh anggota sekolah.

Norms; budaya organisasi di sekolah ditandai pula oleh adanya norma-norma yang berisi tentang standar perilaku dari anggota sekolah, baik bagi siswa maupun guru. Standar perilaku ini bisa berdasarkan pada kebijakan intern sekolah itu sendiri maupun pada kebijakan pemerintah daerah dan pemerintah pusat. Standar perilaku siswa terutama berhubungan dengan pencapaian hasil belajar siswa, yang akan menentukan apakah seorang siswa dapat dinyatakan lulus/naik kelas atau tidak. Standar perilaku siswa tidak hanya berkenaan dengan aspek kognitif atau akademik semata namun menyangkut seluruh aspek kepribadian. Sedangkan berkenaan dengan standar perilaku guru, tentunya erat kaitannya dengan standar kompetensi yang harus dimiliki guru, yang akan menopang terhadap kinerjanya. Dalam perspektif kebijakan pendidikan nasional, pemerintah telah merumuskan empat jenis kompetensi guru sebagaimana tercantum dalam Penjelasan Peraturan Pemerintah No 14 Tahun 2005 tentang Standar Nasional Pendidikan, yaitu: (1) Kompetensi pedagogik yaitu merupakan kemampuan dalam pengelolaan peserta didik yang meliputi: pemahaman wawasan atau landasan kependidikan, pemahaman terhadap peserta didik, pengembangan kurikulum/silabus, perancangan pembelajaran, pelaksanaan pembelajaran yang mendidik dan dialogis, evaluasi hasil belajar, dan pengembangan peserta didik untuk mengaktualisasikan berbagai potensi yang dimilikinya; (2) Kompetensi kepribadian yaitu merupakan kemampuan kepribadian yang: mantap, stabil, dewasa, arif dan bijaksana, berwibawa, berakhlak mulia, menjadi teladan bagi peserta didik dan masyarakat, mengevaluasi kinerja sendiri, dan mengembangkan diri secara berkelanjutan. (3) Kompetensi sosial yaitu merupakan kemampuan pendidik sebagai bagian dari masyarakat untuk: berkomunikasi lisan dan tulisan, menggunakan teknologi komunikasi dan informasi secara fungsional, bergaul secara efektif dengan peserta didik, sesama pendidik, tenaga kependidikan, orangtua/wali peserta didik, dan bergaul secara santun dengan masyarakat sekitar. (4) Kompetensi profesional merupakan kemampuan penguasaan materi pembelajaran secara luas dan mendalam yang meliputi: konsep, struktur, dan metoda keilmuan/teknologi/seni yang menaungi/koheren dengan materi ajar, materi ajar yang ada dalam kurikulum sekolah, hubungan 
konsep antar mata pelajaran terkait, penerapan konsep-konsep keilmuan dalam kehidupan seharihari, dan kompetisi secara profesional dalam konteks global dengan tetap melestarikan nilai dan budaya nasional.

Dominant values; jika dihubungkan dengan tantangan pendidikan Indonesia dewasa ini yaitu tentang pencapaian mutu pendidikan, maka budaya organisasi di sekolah seyogyanya diletakkan dalam kerangka pencapaian mutu pendidikan di sekolah. Nilai dan keyakinan akan pencapaian mutu pendidikan di sekolah hendaknya menjadi hal yang utama bagi seluruh warga sekolah. Dalam konteks Manajemen Peningkatan Mutu Berbasis Sekolah (Depdiknas, 2001), mutu pendidikan meliputi aspek input, proses dan output pendidikan. Pada aspek input, mutu pendidikan ditunjukkan melalui tingkat kesiapan dan ketersediaan sumber daya, perangkat lunak, dan harapan-harapan. Makin tinggi tingkat kesiapan input, makin tinggi pula mutu input tersebut. Sedangkan pada aspek proses, mutu pendidikan ditunjukkan melalui pengkoordinasian dan penyerasian serta pemanduan input sekolah dilakukan secara harmonis, sehingga mampu menciptakan situasi pembelajaran yang menyenangkan (enjoyable learning), mampu mendorong motivasi dan minat belajar, dan benar-benar mampu memberdayakan peserta didik. Sementara, dari aspek out put, mutu pendidikan dapat dilihat dari prestasi sekolah, khususnya prestasi siswa, baik dalam bidang akademik maupun non akademik.

Philosophy; budaya organisasi ditandai dengan adanya keyakinan dari seluruh anggota organisasi dalam memandang tentang sesuatu secara hakiki, misalnya tentang waktu, manusia, dan sebagainya, yang dijadikan sebagai kebijakan organisasi. Jika kita mengadopsi filosofi dalam dunia bisnis yang memang telah terbukti memberikan keunggulan pada perusahaan, di mana filosofi ini diletakkan pada upaya memberikan kepuasan kepada para pelanggan, maka sekolah pun seyogyanya memiliki keyakinan akan pentingnya upaya untuk memberikan kepuasan kepada pelanggan. Dalam konteks Manajemen Peningkatan Mutu Berbasis Sekolah, Depdiknas (2001) mengemukakan bahwa: "pelanggan, terutama siswa harus merupakan fokus dari semua kegiatan di sekolah. Artinya, semua in put - proses yang dikerahkan di sekolah tertuju utamanya untuk meningkatkan mutu dan kepuasan peserta didik. Konsekuensi logis dari ini semua adalah bahwa penyiapan in put, proses belajar mengajar harus benar-benar mewujudkan sosok utuh mutu dan kepuasan yang diharapkan siswa."

Rules; budaya organisasi ditandai dengan adanya ketentuan dan aturan main yang mengikat seluruh anggota organisasi. Setiap sekolah memiliki ketentuan dan aturan main tertentu, baik yang bersumber dari kebijakan sekolah setempat, maupun dari pemerintah, yang mengikat seluruh warga sekolah dalam berperilaku dan bertindak dalam organisasi. Aturan 
umum di sekolah ini dikemas dalam bentuk tata- tertib sekolah (school discipline), di dalamnya berisikan tentang apa yang boleh dan tidak boleh dilakukan oleh warga sekolah, sekaligus dilengkapi pula dengan ketentuan sanksi, jika melakukan pelanggaran. Joan Gaustad (1992) dalam tulisannya tentang School Discipline yang dipublikasikan dalam ERIC Digest 78 mengatakan bahwa: "School discipline has two main goals: (1) ensure the safety of staff and students, and (2) create an environment conducive to learning.

Organization climate; budaya organisasi ditandai dengan adanya iklim organisasi. Hay Resources Direct (2003) mengemukakan bahwa "organizational climate is the perception of how it feels to work in a particular environment. It is the "atmosphere of the workplace" and people's perceptions of "the way we do things here." Di sekolah terjadi interaksi yang saling mempengaruhi antara individu dengan lingkungannya, baik lingkungan fisik maupun sosial. Lingkungan ini akan dipersepsi dan dirasakan oleh individu tersebut sehingga menimbulkan kesan dan perasaan tertentu. Dalam hal ini, sekolah harus dapat menciptakan suasana lingkungan kerja yang kondusif dan menyenangkan bagi setiap anggota sekolah, melalui berbagai penataan lingkungan, baik fisik maupun sosialnya. Moh. Surya (1997) menyebutkan bahwa: "Lingkungan kerja yang kondusif baik lingkungan fisik, sosial maupun psikologis dapat menumbuhkan dan mengembangkan motif untuk bekerja dengan baik dan produktif. Untuk itu, dapat diciptakan lingkungan fisik yang sebaik mungkin, misalnya kebersihan ruangan, tata letak, fasilitas dan sebagainya. Demikian pula, lingkungan sosial-psikologis, seperti hubungan antar pribadi, kehidupan kelompok, kepemimpinan, pengawasan, promosi, bimbingan, kesempatan untuk maju, kekeluargaan dan sebagainya. “

\section{Arti Penting Pengelolaan Multi Budaya dalam Budaya Organisasi di Sekolah}

Pentingnya membangun budaya organisasi di sekolah, dalam konteks manjemen multi budaya, terutama berkenaan dengan upaya pencapaian tujuan pendidikan sekolah dan peningkatan kinerja sekolah. Sebagaimana disampaikan oleh Stephen Stolp (1994) tentang School Culture yang dipublikasikan dalam ERIC Digest, dari beberapa hasil studi menunjukkan bahwa budaya organisasi di sekolah berkorelasi dengan peningkatan motivasi dan prestasi belajar siswa serta kepuasan kerja dan produktivitas guru. Begitu juga, studi yang dilakukan Leslie J. Fyans, Jr. dan Martin L. Maehr tentang pengaruh dari lima dimensi budaya organisasi di sekolah yaitu: tantangan akademik, prestasi komparatif, penghargaan terhadap prestasi, komunitas sekolah, dan persepsi tentang tujuan sekolah menunjukkan survey terhadap 16310 siswa tingkat empat, enam, delapan dan sepuluh dari 820 sekolah umum di Illinois, mereka 
lebih termotivasi dalam belajarnya dengan melalui budaya organisasi di sekolah yang kuat. Sementara itu, studi yang dilakukan, Jerry L. Thacker and William D. McInerney terhadap skor tes siswa sekolah dasar menunjukkan adanya pengaruh budaya organisasi di sekolah terhadap prestasi siswa. Studi yang dilakukannya memfokuskan tentang new mission statement, goals based on outcomes for students, curriculum alignment corresponding with those goals, staff development, and building level decision-making. Budaya organisasi di sekolah juga memiliki korelasi dengan sikap guru dalam bekerja. Studi yang dilakukan Yin Cheong Cheng membuktikan bahwa "stronger school cultures had better motivated teachers. In an environment with strong organizational ideology, shared participation, charismatic leadership, and intimacy, teachers experienced higher job satisfaction and increased productivity”.

Upaya untuk mengembangkan budaya organisasi di sekolah terutama berkenaan tugas kepala sekolah selaku leader dan manajer di sekolah. Dalam hal ini, kepala sekolah hendaknya mampu melihat lingkungan sekolahnya secara holistik, sehingga diperoleh kerangka kerja yang lebih luas guna memahami masalah-masalah yang sulit dan hubungan-hubungan yang kompleks di sekolahnya. Melalui pendalaman pemahamannya tentang budaya organisasi di sekolah, maka ia akan lebih baik lagi dalam memberikan penajaman tentang nilai, keyakinan dan sikap yang penting guna meningkatkan stabilitas dan pemeliharaan lingkungan belajarnya.

\section{Daftar Sumber}

Elashmawi, Farid \& Philip R. Haris, 1999. Manajemen Multi Budaya, Kecakapan Baru Demi Sukses Global (terjemahan). PT Gramedia Pustaka Utama. Jakarta.

Depdiknas. 2001. Manajemen Peningkatan Mutu Berbasis Sekolah; Buku 1 Konsep dan Pelaksanaan. Jakarta : Direktorat SLTP Dirjen Dikdasmen,

Fred Luthan. 1995. Organizational Behavior. Singapore: McGraw-Hill,Inc.

Hay Group. 2003 "Intervention: Managerial Style \& Organizational Climate Assessment”. (http://www. Misc/style_climate_intervention.asp.)

Joan Gaustad. "School Discipline" (http://eric.uoregon.edu/publications/ digests/digest078.html ). ERIC Digest 78. December 1992

Larry Lashway. Ethical Leadership. http://eric.uoregon.edu/publications/digests/digest107.html). ERIC Digest. Number 106. June 1996.

Moh. Surya .1995. Nilai-Nilai Kehidupan (makalah) . Kuningan : PGRI PD II Kuningan

Sumadi Suryabrata. 1990. Psikologi Kepribadian. Jakarta : CV Rajawali.

Sugiri, Sugiri \& Sulfemi, Wahyu Bagja. (2011). Pendidikan Multi Kultur di Sekolah Berbasis Keagamaan. Edutecno. 3 (2), 11-20. 
Sulfemi, Wahyu Bagja. (2007). Ilmu Sosial Dasar. Bogor : STKIP Muhammadiyah Bogor

Sulfemi, Wahyu Bagja. (2015). Kemampuan Pedagogik Guru. Prosiding Seminar Nasional. STKIP Muhammadiyah Bogor 1. (1). 71-83.

Sulfemi, Wahyu Bagja. (2016). Kompetensi Profesionalisme Guru Indonesia dalam Menghadapi MEA. Prosiding Seminar Nasional STKIP Muhammadiyah Bogor. 1 (1), 62-77.

Sulfemi, Wahyu Bagja. (2016). Modul Pembelajaran Ilmu Sosial dan Budaya Dasar. Bogor : STKIP Muhammadiyah Bogor.

Sulfemi, Wahyu Bagja. (2016). Perundang-Undangan Pendidikan. Bogor : Program Studi Administrasi Pendidikan STKIP Muhammadiyah Bogor.

Sulfemi, Wahyu Bagja. (2018). Manajemen Kurikulum di Sekolah. Bogor : Visi Nusantara Maju.

Sulfemi, Wahyu Bagja. (2018). Modul Manajemen Pendidikan Non Formal. Bogor: STKIP Muhammadiyah Bogor

Sulfemi, Wahyu Bagja., \& Yuliana, Desi. (2019). Penerapan Model Pembelajaran Discovery Learning Meningkatkan Motivasi dan Hasil Belajar Pendidikan Kewarganegaraan. Jurnal Rontal Keilmuan Pancasila dan Kewarganegaraan. 5 (1), 17-30.

Sulfemi, Wahyu Bagja. (2019). Manajemen Pendidikan Berbasis Multi Budaya. Bogor : STKIP Muhammadiyah Bogor .

Sulfemi, Wahyu Bagja (2019). Model Pembelajaran Kooperatif Mind Mapping Berbantu Audio Visual Dalam Meningkatkan Minat, Motivasi dan Hasil Belajar IPS. Jurnal Pendidikan Ilmu Pengetahuan Sosial Indonesia (PIPSI). 4 (1), 13 - 19. 